\title{
ContinUing Offences
}

\section{DaVID Ross QC}

[A continuing offence is one which takes more than one act to prove the charge. Probably the best known is consorting but there are others. New legislation has introduced some serious continuing offences. Stalking and maintaining a sexual relationship with a young person are two of them. Others are hybrids: those which can be proved by one act or many. The best examples are drug trafficking or supplying. I examine them all. They are exceptions to the basic legal principle of one criminal act for each charge. I finish with a possible jury direction.]

\section{INTRODUCTION}

Some offences are of their very nature continuing offences. By that I mean that the evidence of a number of criminal acts is required to prove the single offence. Thus one count or charge properly recites the crime. Those continuing offences originally included consorting and other offences which often have gerunds as a description of the offence: keeping, living, suffering, permitting and frequenting are some of them. These offences are all statutory and seem to have been intended to be dealt with summarily. ${ }^{1}$ They are social order offences designed to avoid nuisance being caused to citizens of good morals and sober habits. The gaming offences were obviously intended to protect young men of sporting inclination from being taken down by cardsharps and cheats. The bawdy house offences are designed to safeguard public morals. These are offences that have been on the books for well over a century. In Hussein Buchanan JA said, "Continuous offences are well known to

\footnotetext{
${ }^{*}$ Of the Victorian Bar. Admitted as silk throughout Australia and in Guyana.
} 
the law, especially in cases of conspiracy, public nuisance, harassment and certain statutory offences such as living on the earnings of a prostitute."

But in more recent times other serious statutory offences have been introduced. Maintaining a sexual relationship with a young person is a serious offence. To make out the offence a number of sexual acts with a child must be proved. The general rule is that there is to be only one criminal act per count because otherwise there is an irresistible implication of the accused's propensity to commit crimes in general or certain crimes in particular. That general rule is abrogated by the statute by which this offence is created. The statutory offence of stalking falls into the same category.

There are yet other offences which will allow evidence to be given of more than one criminal act if that is the nature of the prosecution case. Conspiracy is a good example. But there are other very serious offences which fall into this category. They are the offences which involve carrying on the business of drug dealing. In the prosecution of a single count of that serious offence the prosecution can lead evidence of a number of drug deals. The purpose of this article is to examine what are and what are not continuing offences, to see how the courts have interpreted the legislation which creates those offences, and to derive from these what a jury is to be directed by a judge.

\section{Discrete Offences}

First I will look briefly at what have been regarded as wrongly charging continuing offences by allowing evidence of more than one criminal act in one charge.

The starting point is Walsh v Tattersall. ${ }^{3}$ The High Court of Australia found 3-2 that false applications for social security benefits are discrete offences. It was not proper to regard them as continuous by charging them all as one offence. Other Victorian Court of Criminal Appeal decisions were to the same effect. In Trotter ${ }^{4}$ the accused had been charged with what was in effect one indecent assault. The victim gave evidence of two events. The Court held that only one event should have been allowed to be decided by the jury, and because of the evidence of the two the jury's verdict was either uncertain or lacked unanimity. The principle in Trotter has been later applied. ${ }^{5}$

\footnotetext{
${ }^{1}$ Some of the old offences have been abolished in Australia such as being a rogue or vagabond. But while the offence existed, a single charge of a number of acts was not bad for duplicity: Loftus v Woodworth [1936] VLR 279; Walsh v. Tattersall, (1996) 188 CLR 77, 91. (For some history of that offence see Ledwith v. Roberts, [1937] 1 KB 232).

${ }^{2}$ DPP (Cth) v. Hussein, (2003) 8 VR 92, 97. Buchanan JA gave the leading judgment of the Court of Appeal.

3 Walsh v. Tattersall, (1996) 186 CLR 77.

${ }^{4} \mathrm{R}$ v. Trotter, (1982) 7 A Crim R 8 (Vic CCA).

${ }^{5}$ R v. Suckling, (1998) 104 A Crim R 59 (Vic CCA).
} 
Latent ambiguity is the term used in Johnson $v$ Miller ${ }^{6}$ to describe evidence of more than one act led on a single count. It has also been described as latent uncertainty. ${ }^{7}$ Kirby J summed it up: “....save for statutory warrant and for the exceptional cases of continuing offences or facts so closely related that they amount to the one activity, separate offences should be the subject of separate charges." ${ }^{8}$ Some further examples. The wrongful erection of an advertising sign was not a continuing offence notwithstanding that defendant kept it there for some time. ${ }^{9}$ Nor was an offence of having an unsafe work environment. ${ }^{10}$ Escape from custody occurs when the break for freedom is made. It is not a continuing offence of being at large. ${ }^{11}$

\section{Continuing Offences}

Now something of continuing offences, that is those which require proof of a number of acts to make out the single offence.

\section{A Consorting}

Legislation creates the offence of consorting. Typically it is expressed in the following way:

A person who habitually consorts with reputed thieves, prostitutes or persons having no lawful visible means of support is guilty of an offence ${ }^{12}$

Consorting means "some seeking or acceptance of the association with other specified persons on the part of a defendant (Brown v Bryan [1963] Tas SR 1 at 2)" ${ }^{13}$

By the legislation the consorting must be habitual. In Dias $v$ O'Sullivan Mayo $\mathrm{J}$ said:

'Habitually' requires a continuance and permanence of some tendency, something that has developed into a propensity, that is present from day to day. A habit results from a condition of mind that has become stereotyped. In terms of conduct its presence is demonstrated by the frequency of acts that by repetition have acquired the characteristic of being customary or usual; behaviour that is to be regarded as almost inevitable when the appropriate conditions are present. The tendency will ordinarily be required

\footnotetext{
6 Johnson v. Miller, (1937) 59 CLR 467, per Dixon J at 486.

${ }^{7}$ R v.Walsh, (2002) 131 A Crim R 299 (Vic CA) per Phillips and Buchanan JJ at 309.

${ }^{8}$ Walsh v. Tattersall, (1996) 186 CLR 77, 112.

${ }^{9}$ Superliquorman Hotels (Napier) Ltd v. Napier City Council, [1984] 1 NZLR 58, 60-61 (CA).

${ }^{10}$ Chugg v. Pacific Dunlop Ltd, [1988] VR 411; Meiklejohn v. Central Norseman Gold Corporation Ltd, (1998) 19 WAR 298.

${ }^{11}$ R v. Scott, [1967] VR 276 (CCA) per Smith J at 285-6.

${ }^{12}$ Vagrants, Gaming and other Offences Act, 1931, s 4(1)(d) (Qld); Police Act, 1892, s 65(9) (WA); Police Offences Act, 1935, s 6 (Tas); Summary Offences Act s 56(1)(I) (NT); Crimes Act ,1900, s 546A (NSW); Vagrancy Act, 1958, s 6(c) (Vic); Summary Offences Act, 1953, (SA) s 13. There is no equivalent legislation in ACT but Legislation Act 2001 deals with continuingg offences without naming any.

${ }^{13}$ Johanson v. Dixon, (1979) 143 CLR 376, 383 (Mason J) and 395 (Aickin J).
} 
to be demonstrated by numerous instances of reiteration. ${ }^{14}$ (emphasis added)

So in Jan $v$ Fingleton ${ }^{15}$ the information was held proper which contained one count charging the offence between given dates.

\section{B Keeping a brothel (bawdy house)}

Keeping an unlicensed brothel is an offence created by legislation ${ }^{16}$ although it may also be an offence at common law. ${ }^{17}$

"Keeping" imports that the person is carrying on his own business or is managing those premises. ${ }^{18}$ The offence is made out if the premises are used to organize assignations. ${ }^{19}$ But it must be a business. A woman on her own receiving callers does not keep a bawdy house. ${ }^{20}$

\section{Keeping a common gaming house}

Legislation prohibits the keeping of a common gaming house. ${ }^{21}$ I will not deal with the question of what is a prohibited game, however described.

Most of the legislation refers to a common gaming house being "kept or used". The words have been held to import the carrying on of a business. ${ }^{22}$ Thus "kept" would have the same meaning as in keeping a brothel. "Used" has been interpreted as not including the playing of an unlawful game once between friends. ${ }^{23}$ Salmond $\mathrm{J}$ said:

A gaming house is the place of business of a man who in the way of business affords facilities to others to indulge in the practice of gaming there either with himself or with themselves. ${ }^{24}$

\footnotetext{
${ }^{14}$ Dias v. O’Sullivan, [1949] SASR 195, 200-201.

${ }^{15}$ Jan v. Fingleton, (1983) 32 SASR 379; 9 A Crim R 293 (FC).

${ }^{16}$ Criminal Code, s 209 (WA); Criminal Code, s 143 (Tas); Prostitution Regulation Act, s 4 (NT); Summary Offences Act, 1988, s 17 (NSW); Prostitution Control Act 1994 (Vic); Criminal Law Consolidation Act s 270(1); Summary Offences Act, 1953, s 28 (SA); Prostitution Act 1992 (ACT).

${ }^{17}$ R v. Rahme, (1993) 70 A Crim R 357 (NSW CCA).

${ }^{18}$ R v. Rahme, (1993) 70 A Crim R 357, 364 (NSW CCA).

${ }^{19}$ Samuels v. Bosch, (1972) 127 CLR 517 (High Court of Australia, 1972); Ferricks v. Guzikowski, (1990) 51 A Crim R 78 (Qld FC).

${ }^{20}$ R v. Krausky, [1990] 2 Qd R 177.

${ }^{21}$ Criminal Code, s 232 (Qld); Gaming Commission Act 1987, s 41 (WA); Racing and Gaming Act, 1952, ss 93 and 112 (Tas); Gaming Act, s 60 (NT); Unlawful Gambling Act 1998, ss 4 and 48 (NSW); Lotteries Gaming and Betting Act 1966, s 12 (Vic); Lottery and Gaming Act 1936, s 4 (SA); Gaming and Betting Act 1903, s 3 (ACT).

${ }^{22}$ Dolling v. Bird, [1924] NZLR 545.

${ }^{23}$ R v. Davies, [1897] 2 QB 199 (CCR).

${ }^{24}$ Weathered v. Fitzgibbon, [1925] NZLR 331.
} 


\section{Living on the earnings of prostitution}

There is no corresponding offence at common law. The legislation in such jurisdictions as deal with the activity creates an offence where a person "...knowingly lives wholly or in part on the earnings of prostitution". 25

I will not concern myself with the provisions which deal with proof. My interest is to examine how the courts interpret "live in whole or in part". The word "living" seems like a continuous activity. The case of $R v$ Hill $^{26}$ points up some real difficulties of interpretation of "living". Strange to say this case was prosecuted on indictment and the conviction was hence by jury verdict. The court found this mode of prosecution proper. But on the issue of the framing of the charge and on the admissibility of evidence, the arguments of counsel for the appellant are more fully set out in the Criminal Appeal Report. Mr Hill had been convicted of living in part on the earnings of one prostitute on a certain day and of another prostitute on the same day. Each charge was contained in a separate count. It seems that evidence was also given of other, what must have been similar, acts of Mr Hill with one of the prostitutes. I assume it would have been making assignations or taking money. The argument was put that it was impossible to conceive of one day as "living". The alternative argument is better described as a paradox. Notwithstanding that one day could not be described as living, the introduction of evidence of his activities on other days was the cause of prejudice and embarrassment. The Court of Criminal Appeal in a shorter than one page judgment which was the judicial fashion of the day, disposed of this argument briefly:

He was indicted for having lived on the earnings of prostitution upon one specified day only, and it was contended that the indictment was therefore bad. It was also contended that evidence was not admissible on the indictment as laid, of anything done on any day except the day specified. We do not agree with either contention. The indictment charging the offence on that way is perfectly good, and there is no ground for saying that evidence is not admissible to show what the appellant's relations with the woman in question had been either before or after the day specified on the indictment, as such evidence is clearly relevant to the question whether he was or was not, on the day specified, living on the earnings of her prostitution. $^{27}$

\footnotetext{
${ }^{25}$ Police Act 1892, s 76G(1) (WA); Summary Offences Act 1988, s 15(1) (NSW); Prostitution Control Act 1994, s 10(1) (Vic); Summary Offences Act 1953, s 26(1) (SA).

${ }^{26}$ R v. Hill; R v. Churchman, [1914] 2 KB 386; 10 Cr App R 56 (CCA).

${ }^{27}$ R v. Hill, [1914] KB 389-390 (CCA). Cr App R has a different version.
} 


\section{E Suffering}

Suffering prostitutes to assemble in a refreshment house was once an offence. ${ }^{28}$ In Csomor v Haberman ${ }^{29}$ Herring CJ approved an appeal which had struck out the conviction of $\mathrm{Mr}$ Csomor. The evidence given in the case is instructive. Mr Csomor ran the "Red Tulip" restaurant at 135 Bridge Road Richmond, Victoria. It provided meals. There was a small dance floor. The charge was that the defendant "on 23 February 1958 did suffer prostitutes or persons of notoriously bad character to be assembled in premises known as the 'Red Tulip' restaurant". The evidence was that police visited the restaurant on 23 February and saw five women there whom they identified as prostitutes. The police pointed them out to Mr Csomor. More interesting for present purposes was the police evidence that on a number of occasions in the previous two months they had visited the restaurant, seen prostitutes there and had pointed them out to Mr Csomor. Some of those prostitutes there earlier were present on the night in question. The conviction was set aside because there was no suggestion that any of the prostitutes at the restaurant were there to pursue their trade profession or calling individually or in company. I assume that the judgement means that they were not there for that purpose on 23 February, but it may also mean that they were never there for that purpose. Even prostitutes have to eat somewhere. Conspicuous by its absence in the judgment is any suggestion that the police evidence of what was seen and done on their visits before 23 February was improperly received. I suspect that the reason for this is that "suffers" imputes a continuous offence so as to make such evidence admissible.

Lest this piece of legislation sounds like a voice from another world, the offence still exists in a modified form. In Victoria, Summary Offences Act 1966 s 20(1) provides:

Any person who allows in any house building tent or other premises wherein liquors provisions or refreshments are sold or disposed of any drunkenness or other disorderly conduct or suffers persons of notoriously bad character to frequent his premises shall be guilty of an offence. (emphasis added).

The new section is more likely to allow evidence of other acts because of the use of the verb "frequent".

The word suffer can also seemingly include a continuous act on one occasion. In Douglas-Brown v Commissioner of Police ${ }^{30}$ the liquidator of the Castle Hotel was alleged to have been in breach of the liquor licence by allowing scantily dressed young ladies to dance in a lewd manner in the hotel. That is legalese for strippers. It was never part of the case that there was only one act. The ladies put on performances. A similar example can be found in permitting a person to drive and keep on driving. ${ }^{31}$

\footnotetext{
${ }^{28}$ Police Offences Act 1957 (Vic), s 32.

${ }^{29}$ Csomor v. Haberman, [1960] VR 153 (Herring CJ).

${ }^{30}$ Douglas-Brown v. Commissioner of Police, (1995) 13 WAR 41 (FC).

${ }^{31}$ Evans v. Accident Insurance Insurance Mutual Holdings \& Anor, (1997) 26 MVR 83 (Qld CA).
} 
And when a landlord knew that his demised premises were being unlawfully used, had the power to prevent that use and did not prevent it, he was said to "suffer" a use contrary to the Development Act 1993 (SA). ${ }^{32}$

\section{F Permitting}

Permitting connotes a continuing activity. In Proudman v Dayman ${ }^{33}$ Mrs Proudman was convicted of "permitting" an unlicensed person to drive. Young v Australian Workers' Union ${ }^{34}$ turned on whether Mr and Mrs Young had permitted two shearers they employed to use wide comb shears. There were separate complaints for each shearer, but it seems implicit in the facts referred to in the judgment that each shearer used wide combs for the whole of one day.

It is not unusual for a statute proscribing an offence to characterise the act as "suffer or permit". An example was the charge in Rahme. In Tasmania a person occupying premises shall not "permit or suffer any breach of the peace" (Police Offences Act 1935 s 10). In WA it is an offence to "permit or suffer prostitutes...to meet together and remain" in certain premises (Police Act 1892 s 84).

But permit, as a verb, seems to be used to refer at least to a prolonged event. Sweet $v$ Parsley ${ }^{35}$ and $R v$ Souter ${ }^{36}$ both turned on the construction of permitting premises to be used for the smoking of cannabis (contrary to statute) when in each case it was clear that the smoking had gone on for a considerable time.

\section{G Frequent}

Frequent as a verb appears in a number of statutes. I have already referred to Summary Offences Act 1966 (Vic) s 20. Another example comes from South Australia. There it is an offence to be the occupier of premises "frequented by reputed thieves prostitutes..." and other specified persons (Summary Offences Act 1953 s 21).

The word is in legislation of long standing. Two examples from the cases will suffice. Annie Macmanamny was charged in 1899 with "being a suspected person she did frequent Elizabeth Street Melbourne with intent to commit a felony". A'Beckett J confirmed her conviction but observed "evidence of presence in the street on one day would not justify a conviction under the section". 37 Edward Whiting was held to have been properly convicted of being the occupier of a house frequented by reputed thieves. Hood J found "The fact that five reputed

\footnotetext{
${ }^{32}$ Wright v. City of West Torrens Corporation, (1996) 91 LGERA 197.

${ }^{33}$ Proudman v. Dayman, (1941) 67 CLR 536.

${ }^{34}$ Young v. Australian Workers' Union, (1974) 5 ALR 347 (Aust Ind Ct).

${ }^{35}$ Sweet v. Parsley, [1970] AC 132 (HL).

${ }^{36} \mathrm{R}$ v. Souter, [1971] 1 WLR 1187 (CCA).

${ }^{37}$ Macmanamny v. Harcourt, (1899) 25 VLR 47, 49-50 (A’Beckett J).
} 
thieves...were found there on three occasions is sufficient evidence of frequenting." 38

These legislative provisions show that more than one act is required to be proved in order to make out the offence.

\section{H Stalking}

Another gerund. The offence is one that has had only recent legislative recognition. $^{39}$

It is abundantly clear from the legislation in each jurisdiction that the proof of the offence requires evidence of a course of conduct or of at least two separate acts. In construing the Victorian legislation in Gunes v Pearson, McDonald J said:

For a person to engage in conduct which attracts the application of s $21 \mathrm{~A}$ of the Crimes Act that which must be engaged in must be a course of conduct ... which is protracted or conduct which must be engaged in on more than one occasion. ${ }^{40}$

On the occasions which the prosecution allege, the prosecution must prove each act beyond reasonable doubt. ${ }^{41}$

\section{Maintaining a sexual relationship with a young person}

Again, this offence was created by fairly recent legislation. ${ }^{42}$ The conduct made criminal is having continuing sexual dealings with a person under a certain age. It is an extended version of what used to be called carnal knowledge. In those old sections sexual intercourse was prohibited with any girl under the age of 16 years, and if the man were 21 or older, there was to be no intercourse with a girl under 18 years. Consent of the girl was no defence.

Where there is more than one sexual act with a person who is under the prescribed age, the offence is maintaining a sexual relationship with a young person (Different jurisdictions may describe the offence differently, but the meaning is the same). Again, consent is no defence. The culpability of the offences can be gauged by the difference in penalty. In Victoria for example, an act of sexual penetration with a

\footnotetext{
${ }^{38}$ Coonan v. Whiting, [1919] VLR 548, 541 (Hood J).

${ }^{39}$ Criminal Code s 359A (Qld); Criminal Code s 338D (WA); Criminal Code s 192 (Tas); Criminal Code s 189 (NT); Crimes Act 1900, s 562AB (NSW); Crimes Act 1958, s 21A (Vic); Criminal Law Consolidation Act, 1935, s 19AA (SA); Crimes Act, 1900, s 35 (ACT).

${ }^{40}$ Gunes v. Pearson, (1996) 89 A Crim R 297, 306 Vic, McDonald J).

${ }^{41}$ R v. Hubbuck, [1999] 1 Qd R 314 (CA )

${ }^{42}$ Criminal Code, s 229B (Qld); Criminal Code, s 321A (WA); Criminal Code, s 125A and 337B (Tas); Criminal Code, s 131A (NT); Crimes Act 1900, s 66EA (NSW); Crimes Act 1958, s 47A (Vic); Criminal Law Consolidation Act 1935, s 74 (SA); Crimes Act 1900, s 92EA (ACT).
} 
child between 10 and 16 attracts a maximum of 10 years imprisonment. Maintaining a sexual relationship with a child under the age of 16 attracts a 25 year maximum. ${ }^{43}$ The essence of this single offence is a number of sexual acts which do not have to be the same sort.

The elements of this offence were isolated by Malcolm CJ in $R v G P$. His Honour said:

The offence...is committed when, on three or more separate days, a person does an act in relation to a child which would constitute an act of sexually penetrating or indecent dealing with the child. The fact that the child is under the age of 16 years is an element of the offence...The absence of consent is not an element of the offence. ${ }^{44}$

There are some riders. In many charges based on sexual acts, the principal prosecution witness will give evidence of many more sexual encounters than are necessary to prove the case. In that event the jury must be directed that they must agree on the same three acts on the same occasions. ${ }^{45}$ A propensity warning may have to be given but it depends on the circumstances of the case. ${ }^{46}$

\section{Single or ContinUing OfFEnCES}

Some offences may be committed by one act. For example, one act of some drug trading will constitute an offence; but a number of acts can still be the subject of a single charge. In that way the offences are no different from conspiracy.

\section{A Carrying on the business of unlawful trafficking in drugs (QId)}

The offence is created by Drugs Misuse Act 1986 s 5. Clearly enough, from the wording of the section evidence may be led of a number of drug transactions on a single charge. Courts have interpreted the section in that way. ${ }^{47}$

Yet in jurisdictions where the word "trafficking" is used, courts have concluded that the words creating the offence can contemplate a prosecution allegation of carrying on a business. ${ }^{48}$

\footnotetext{
${ }^{43}$ The longest recent sentence was six years imprisonment with a minimum of four years: DPP v. WJW, (2000) 2 VR 497 (CA).

${ }^{44}$ R v. GP, (1997) 18 WAR 196, 199 (CCA).

${ }^{45}$ KBT v. The Queen, (1997) 191 CLR 417.

${ }^{46}$ KRM v. The Queen, (2001) 206 CLR 221

${ }^{47}$ R v. Elhusseini, [1988] 2 Qd R 442; 33 A Crim R 155 (CCA).

${ }^{48}$ Drugs, Poisons and Controlled Substances Act 1981 (Vic) ss 71-71AC; see also Drugs Misuse Act 1986 (Qld) s 5(1); Misuse of Drugs Act 1981 (WA) s 32 A; Misuse of Drugs Act 2001 (Tas) s 12.
} 


\section{B Trafficking in drugs: R v Giretti ${ }^{49}$}

In the interpretation of "trafficking" the courts have held:

1. The offence can be made out by a single act of being "knowingly engaged in the movement of the (specified) drugs from the source to the ultimate user in the course of an illicit trade in such drugs". 50

2. The illicit trade can be conducted "without reward".

3. While possession of itself does not constitute trafficking, the deeming provisions of the legislation contemplate that only slight evidence of acts which might amount to trafficking might be all that is necessary to complete the prosecution case. ${ }^{51}$

4. Trafficking can be a business. Where that is the prosecution case, evidence can be led of many acts of drug dealing on a presentment or indictment containing a single count. ${ }^{52}$ The High Court refused special leave to appeal from Giretti. ${ }^{53}$ More recently the decision seems to have been referred to with approval by the High Court in Walsh $v$ Tattersall. $^{54}$

5. In a Giretti trafficking, the prosecution may allege in one count that the accused was conducting the business of trafficking in drugs and for that purpose leads evidence of a number of transactions. In such a case the prosecution may fail to prove a number of the dealings on which it has relied to show that a business was being conducted. In that event the jury is not to be invited to return a guilty verdict if for example only one transaction is established. When the prosecution alleges business, business must be proved. ${ }^{5}$

6. A presentment may contain a Giretti business of trafficking count followed by counts alleging particular trafficking transactions. ${ }^{56}$

7. An accused can still be charged with conspiracy to traffick a drug of dependence. On such a charge a one count presentment the prosecution can adduce evidence of many acts of drug dealing. ${ }^{57}$

\footnotetext{
${ }^{49}$ R v. Giretti, (1986) 24 A Crim R 112 (CCA).

${ }^{50}$ Falconer v. Pedersen, [1974] VR 185, 188 (Anderson J); R v. Holman, [1982] VR 471, 475 (CCA).

${ }^{51}$ R v. Elem, [1982] VR 295, 299 (CCA).

${ }^{52}$ R v. Giretti, (1986) 24 A Crim R 112 (CCA).

${ }^{53}$ The refusal of special leave does not of itself establish a precedent: Sir Anthony Mason, Use And Abuse of Precedent, 4 AUST RALIAN BAR REV. 93, 96-98 (1988).

${ }^{54}$ Walsh v. Tattersall, (1996) 188 CLR 77, 87 (Dawson and Toohey JJ), and at 93, 104 and 108 (Kirby J) . In KRM v. The Queen, (2001) 206 CLR 221, 260 Kirby J again referred to Giretti with approval. The only reservation expressed by Kirby $\mathrm{J}$, is that the jury should be given a strong propensity warning.

${ }^{55} \mathrm{R}$ v. Komljenovic, (1994) 76 A Crim R 521, 550 (Vic CCA).

${ }^{56}$ R v. Te, [1998] 3 VR 566, 575-578; 97 A Crim R 386, 395-399 (CA).

${ }^{57}$ R v. Guy, (1991) 57 A Crim R 21 (Vic CCA).
} 


\section{Supplying drugs ${ }^{58}$}

The propositions on "supply" accord with the position on "trafficking". In Hamzy ${ }^{59}$ Hunt CJ at CL approved Locchi ${ }^{60}$ and said (at 348):

...the Crown is entitled to plead in the one count a charge of supply where it intends to prove a number of individual acts of supply by the accused to different people at different times, provided that those acts can fairly and properly be identified as part of the same criminal enterprise or the one criminal activity, but the trial court has power to direct the Crown either to elect or to separate the offences where the indictment would otherwise produce an unfairness to the accused.

The dicta of the High Court in Walsh v Tattersall already referred to also supported Hamzy. In Pinkstone ${ }^{61}$ the High Court reaffirmed the wide ambit of "supply".

\section{Cultivation of drugs}

In $R v$ Whalen $^{62}$ the Court of Criminal Appeal approved the laying of a single count for cultivation of cannabis in different places. The court cited the supply cases of Hamzy and Locchi as their reason.

\section{E Framing the charge}

Where the prosecution alleges a single act of, for example, trafficking in a drug of dependence, the count will simply plead that offence as having taken place on the date alleged. Where the allegation is being involved in the business of trafficking, the count will usually be expressed in the following way:

The Director of Public Prosecutions presents (name of accused) at (place or places) in the State of (named) between the $1^{\text {st }}$ day of January and the $31^{\text {st }}$ day of December 2004 trafficked in a drug of dependence namely (drug identified for example, heroin or methylamphetamine or cannabis $\mathrm{L}$ or 3, 4 methylenedioxy-N-methylamphetamine (MDMA)).

The prosecution will give particulars of the acts on which it relies to show that the trafficking was a business.

\footnotetext{
${ }^{58}$ Each jurisdiction has legislation proscribing supply. See DAVID ROSS QC, CRIME [19.3420] (2002).

${ }^{59}$ R v. Hamzy, (1994) 74 A Crim R 341 (NSW CCA).

${ }^{60}$ R v. Locchi, (1991) 22 NSWLR 309 CCA).

${ }^{61}$ Pinkstone v. The Queen, (2004) 78 ALJR 797; 206 ALR 84.

${ }^{62} \mathrm{R}$ v. Whalen, (2003) 56 NSWLR 454, 469 (CCA).
} 


\section{F $\quad$ Sentencing in drug trafficking}

The sentences in drug trafficking vary as widely as the nature of the offences. At the lowest end of the scale is one who possesses drugs in a sufficient quantity to amount to trafficking. That is to say, no drugs ever change hands. The trafficking is on the single date that the drugs are found in possession. Depending on the amount, such a trafficker may expect a sentence of one year imprisonment or less. ${ }^{63}$ At the other end of the range are those who engage in trafficking as a business, that is they are involved in the passage of drugs on a number of occasions, and amount involved is a commercial quantity as the Acts define. In line with ordinary principles, sentencing depends on the nature of the offence and the quality of the person who commits it. For trafficking in a commercial quantity of heroin a young person may be sentenced to eight years. ${ }^{64}$ For a mature person trafficking in the same drug to sentence will be substantially longer. ${ }^{65}$ The longest sentence I have been able to find is 21 years imprisonment with a minimum of 17 years, approved as proper by the Victorian Court of Appeal. ${ }^{66}$

\section{G Conspiracy}

Conspiracy is complete as a crime when two or more agree to do an unlawful act, or a lawful act by unlawful means. This is not the place to examine the elements, the intent and all the practice on the pleading of the charge. ${ }^{67}$ But while the offence is completed by the agreement alone, the proof is often of many criminal acts from which the agreement may be inferred. There are any number of examples.

\section{Possible DiRection}

As a means of concluding the article, what follows is a possible direction to the jury on a continuing offence charge.

1. The accused is charged with (state offence).

2. This is a criminal case and because of that the prosecution has to prove its case.

3. The elements of the charge are these (list elements).

4. You note that to prove its case the prosecution must prove each of those acts.

5. The standard of proof is the highest known to the law: beyond reasonable doubt.

6. The words beyond reasonable doubt are ordinary English words which mean just what they say.

\footnotetext{
${ }^{63}$ DPP v. Collins, [2004] VSCA 179 (CA).

${ }^{64}$ R v. Phung, (2003) 141 A Crim R 311.

${ }^{65}$ In R v. Dent, (2002) 132 A Crim R 151, 158 (Qld CA) the term of imprisonment was 14 years.

${ }^{66} \mathrm{R}$ v. Tong, [2003] VSCA 15 CA).

${ }^{67}$ See for example JC Smith, Proving Conspiracy, CRIM. L. REV., 386 [1996]; PETER GILlIES, THE LAW

OF CRIMINAL CONSPIRACY ( $2^{\text {nd }}$ ed., 1990); Ross, supra note 58, at [3.4200].
} 
7. In a criminal case the person accused does not have to prove a thing.

8. You must not reason that because you might be satisfied that the accused committed one of those acts that she is the sort of person who would have committed the others.

9. You must deal with the evidence of each act separately (recite the evidence).

10. If you are not satisfied beyond reasonable doubt of one of the acts then your verdict must be not guilty. Only if you are satisfied of the happening of each of the acts can your verdict be guilty. 